\title{
LARVICIDAL ACTIVITY OF LEAF EXTRACTS OF AGERATUM CONYZOIDES AND HYPTIS SUAVEOLENS AGAINST AEDES AEGYPTI
}

\author{
Chude, C.F., Okorie, C.J., Ayegbunam, E.S., Aghalu, U.C. \\ Department of Zoology, Faculty of Bioscience, \\ Nnamdi Azikiwe University Awka, Anambra State
}

\begin{abstract}
Mosquito-borne diseases are the most significant public health risks globally. The potency of ethanolic leaf extracts of Goat weed (Ageratum conyzoides) and Pignut weed (Hyptis suaveolens) as mosquito larvicides under laboratory conditions were investigated. The leaf extracts of test plants were obtained using Soxhlet apparatus. Different test concentrations of $10,8,6,4,2$, and $0 \mathrm{mg} / \mathrm{ml}$ (control) were prepared from stock solution. Twenty larvae of Aedes aegypti were exposed to various concentrations and observations were made for the period of 24 hour. The result indicates that the mean larval mortality of $A$. aegypti was recorded highest at concentration of $10 \mathrm{mg} / \mathrm{ml}(4.92 \pm 3.605)$ and $(3.25 \pm 2.598)$ followed by $8 \mathrm{mg} / \mathrm{ml}(4.50 \pm 2.747)$ and $(2.58 \pm 2.065)$ for leaf extracts of $A$. conyzoides and $H$. suaveolens respectively; hence, no mortality was recorded in the control. There was significant difference $(p<0.05)$ between mortality caused by concentrations and control for both plant extracts. The mean larval mortality rate of $A$. aegypti was recorded highest at 3 hours $(4.33 \pm 3.597)$ and $(3.11 \pm 2.698)$ on exposure to $A$. conyzoides and $H$. suaveolens leaf extracts respectively. There was also significant difference $(p<0.05)$ between the mortality recorded at various time of exposure. The percentage mortality was higher in leaf extracts of Ageratum conyzoides than Hyptis suaveolens but there was no significant difference $(p>0.05)$ between the mean mortality of the two plants extracts. However, the $\mathrm{LC}_{50}$ value for $A$. conyzoides and $\mathrm{H}$. suaveolens were found to be $4.30 \mathrm{mg} / \mathrm{ml}$ and $1.81 \mathrm{mg} / \mathrm{ml}$ respectively for acute 24 hours test. It was recommended that leaf extracts of both plants can be used as larvicides against these insect vectors of public health importance.
\end{abstract}

Keywords - Aedes aegypti, Larvicidal activity, Leaf extracts, $\mathrm{LC}_{50}$ value

\section{INTRODUCTION}

Mosquito-borne diseases are the most significant public health risks globally (Webb, 2008). World health organization, has declared mosquito "public enemy number one" because they represent a significant threat to human health and their ability to act as vector of pathogens that cause different diseases that afflict millions of people worldwide (WHO, 1998). Mosquito alone transmit diseases to more than 700 million people annually and the disease is endemic in more than 100 countries (Jang et al., 2002). Beatty et al. (2007) reported that fifty-five percent $(55 \%)$ of the world's population are at risk of mosquito borne diseases in 124 countries. It is estimated that at least 500 million people suffer from mosquito-borne diseases (Madhumathy et al., 2007).

The medical importance of mosquitoes as vectors for the transmission of serious diseases that cause morbidity, mortality, economic loss, and social disruption can never be over emphasized. These diseases have accounted for huge economic losses, mortality, low productivity and social discrimination in many developing countries (Adeleke et al., 2010) and according to Mgbemena (2010), depending on the species, mosquitoes are vectors of protozoa (e.g. Plasmodium spp.) that cause malaria, the nematode worms that causes filariasis (e.g. Wuchereria bancrofti) and a large number of arboviruses including two which are of great impact in the tropical and subtropical regions (i.e. yellow fever and dengue viruses). The species of Anopheles, Culex and Aedes are important vectors in the transmission of malaria, filariasis, dengue, yellow and Chikungunya fevers respectively (Prajapati et al., 2005). WHO (2014), implicates Aedes mosquito as vectors of diseases, Aedes aegypti is responsible for transmission of Dengue, yellow fever, Chikungunya and Zika virus while Aedes albopictus are responsible for the transmission of Chikungunya, dengue and West Nile Virus.

In the absence of effective prophylactic vaccine against most of the mosquito-borne diseases, it is desirable to find compounds that can effectively control mosquitoes with minimal damage to the environment. Okigbo et al. (2010), stated that, one of the approaches for control of these mosquito-borne diseases is the interruption of the disease transmission, by killing or preventing mosquitoes from biting human being, Larval control (source reduction or suppression) has been identified as one of the most effective methods for the control of mosquito- borne diseases as stated by (Singh et 


\section{International Journal of Engineering Applied Sciences and Technology, 2020 \\ Vol. 4, Issue 10, ISSN No. 2455-2143, Pages 304-309 \\ Published Online February 2020 in IJEAST (http://www.ijeast.com)}

al., 2006). Experience has shown that, aerial toxicants for the eradication of this mosquito are not effective, since it is highly domesticated and many adults rest indoors in hidden places such as closets (Senthilkumar et al., 2008). Mosquito control has become increasingly difficult because of the indiscriminate uses of synthetic chemical insecticides which have an adverse impact on the environment and disturb the ecological balance (Nganjiwa et al., 2015).

Repeated use of these controlling agents has fostered several environmental and health concerns, including disruption of natural biological control systems, outbreaks of other insect species, widespread development of resistance and undesirable effects on non- target organisms (Govindarajan et al., 2013). Due to the severe effects of synthetic pesticides, there is serious need to emphasis on natural, economical, biodegradable and environmental friendly pesticide in the control of pest especially mosquitoes and that is the essence of this research. Natural products are generally preferred because of their less harmful nature to non-target organisms and due to their innate biodegradability. Plants are considered as a rich source of bioactive chemicals (Kamaraj et al., 2008) and therefore an ideal control method is thus the system that uses the natural plant products as alternative to synthetic substances, as they are effective and compatible with human, animal life and the environment (Chaithong et al., 2006).

Several studies showed that plant extracts or essential oils can provide desired larvicidal properties against different species of mosquitoes without causing bad effects to humans (Salunkhe et al., 2011; Kumar et al., 2014; Ansori et al., 2015) and this is the reason for this study.

\section{MATERIALS AND METHOD}

\section{Study Area}

The study was conducted at the permanent site of Nnamdi Azikiwe University and Ifite environs in Awka South Local Government Area of Anambra state, Nigeria. Awka is the capital of Anambra State and located in the lowland rain forest zone of Southern Nigeria. Awka is located between latitude $5^{0}$ $\mathrm{E}$ and $6.25^{\circ} \mathrm{N}$ and longitude $7^{\circ} \mathrm{E}$ and $8^{0} \mathrm{E}$ (Onyido et al, 2010). The environment of Nnamdi Azikiwe University (Permanent site) and Ifite comprises of unharnessed thick forest filled with diversity of living organism in which Aedes aegypti mosquito has been reported by Okeke et al. (2013) to be abundant.

\section{Collection and Identification of Plants}

Twigs of pignut weeds (Hyptis suaveolens) (Plate 1) and goat weed (Ageratum conyzoides) (Plate 2) were collected from the forest of Nnamdi Azikiwe University Awka and were taken to the herbarium section in the Department of Botany Nnamdi Azikiwe University Awka, Anambra State, for identification.

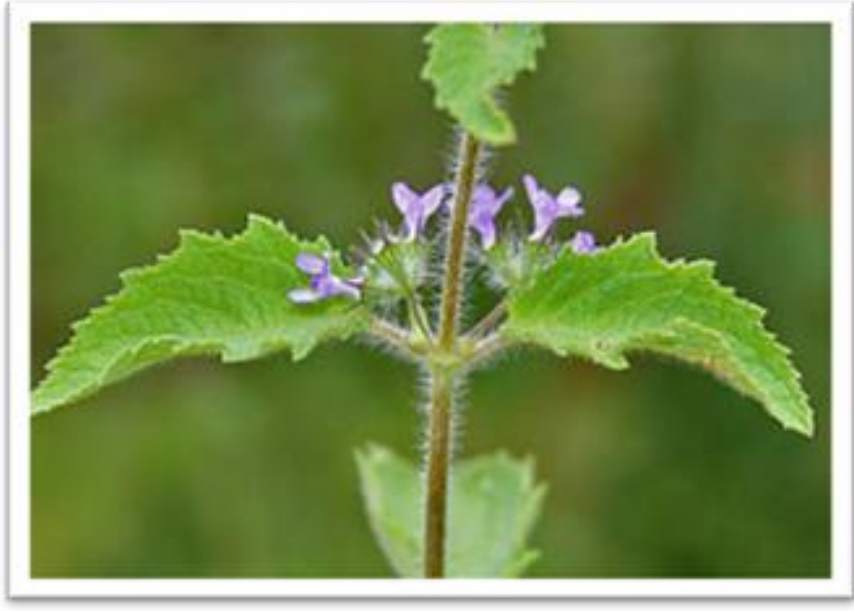

Plate 1: Pignut weed (Hyptis suaveolens)

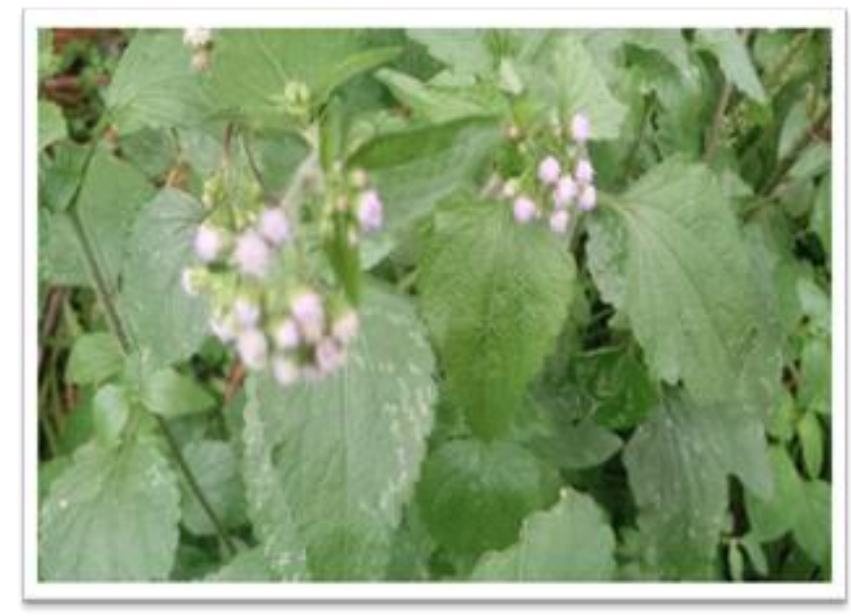

Plate 2: Goat weed (Ageratum conyzoides)

\section{Preparation and Extraction of Test Plants}

Fresh leaves were separated from the twigs and rinsed in water. $50 \mathrm{~g}$ of fresh leaves of Ageratum conyzoides were weighed using electronic balance. The Soxhlet apparatus was set up and the weighed samples were packed into the Soxhlet column to $2 / 3$ its volume. The column was then inserted into the flask and filled with $500 \mathrm{ml}$ of Ethanol (solvent). The soxhlet was then placed on the heating mantle, and heat was adjusted to a temperature of about $78^{\circ} \mathrm{c}$. The solvents were allowed to reflux repeatedly, until refluxing solvent was clear and free from extracts.

The procedures were repeated for pignut weed (Hyptis suaveolens). Both extractions lasted for (6 hrs). The extracted content was transferred into a beaker, and then subjected to rotary vacuum evaporator with water-bath until solvents were completely evaporated to get the solidified crude extracts. The crude extracts thus obtained was stored in sterilized amber 


\section{International Journal of Engineering Applied Sciences and Technology, 2020 \\ Vol. 4, Issue 10, ISSN No. 2455-2143, Pages 304-309 \\ Published Online February 2020 in IJEAST (http://www.ijeast.com)}

coloured bottles and maintained at $4^{\circ} \mathrm{C}$ in a refrigerator. These extraction processes were conducted under room temperature of $\left(28 \pm 1^{0} \mathrm{C}\right)$ in the Laboratory of phytochemical section of National Arbovirus and Vector Research Centre Enugu, Nigeria.

\section{Collections, Identification and Rearing of Aedes Mosquito}

Collections of eggs and larvae were carried out at permanent site of Nnamdi Azikiwe University and Ifite environs, Anambra State. The ovitraps were set under vegetation in five strategic point, larva were also collected from the natural sites such as plastic containers, used tires and stagnant water, the equipment used includes scoop- spoons, bowels, nets and specimen bottles. The eggs were collected from ovitraps, both the eggs and the larvae were sent to the Department of Entomology and Parasitology, National Arbovirus and Vector Research Centre Enugu, Nigeria, for sorting and identification. The larvae were reared under room temperature of about $28 \pm 1^{\circ} \mathrm{c}$ (Ahmad, 2004).

\section{Formulation of Test Materials (Plant Extracts)}

The volume of stock solution for Ageratum conyzoides was obtained by weighing $1 \mathrm{~g}$ of the crude extract and $100 \mathrm{ml}$ of ethanol was added to dissolve it to obtain a concentration of $10 \mathrm{mg} / \mathrm{ml}$. Serial dilutions were made from this stock solution to obtain other test concentration of $10,8,6,4$ and $2 \mathrm{mg} / \mathrm{ml}$. These processes were repeated for Hyptis suaveolens.

\section{Bioassay of Larvae with Plant Extract}

In this present experiment, treatment of larvae with ethanol extracts was conducted in accordance with WHO standard method (WHO, 1986). Twenty (20) larvae of Aedes aegypti were placed in transparent plastic cups of about $40 \mathrm{ml}$ capacity, $15 \mathrm{ml}$ of tap water was added into the cups and was replicated three times. The larvae were then exposed to various concentrations of Ageratum conyzoides and Hyptis suaveolens. Control medium was also maintained with 20 larvae in $15 \mathrm{ml}$ of tap water for each concentration in which $1 \mathrm{ml}$ of ethanol was added. Mortality rates were recorded at 3, 6,9 and $24 \mathrm{hr}$ in laboratory at a room temperature of $28 \pm 1^{\circ} \mathrm{C}$. Each of the test samples and standard were replicated 3 times. This method was modified from Okigbo et al. (2010).

\section{Data Collection and Statistical Analysis}

The data on larvae mortality was first recorded after 3hours, 6 hours, 12 hours and 24hours. It was subjected to analysis of variance using SPSS computer package version 20. The sample means were separated using Duncan multiple range test. The mean percentage mortality of the larva was calculated. One way analysis of variance (ANOVA) was used to compare the mean mortality of Aedes larvae at concentrations and after various time of exposure to the two plants extracts at $5 \%$ significant level.

\section{RESULT}

Mean Larvicidal Mortality of $A$. aegypti exposed to Various Concentrations of $\boldsymbol{A}$. conyzoides and $\boldsymbol{H}$. suavolens after 24 hours

The result shown in Table 1 indicates that the mean larval mortality of $A$. aegypti was recorded highest at $(4.92 \pm 3.605)$ on exposure to concentration of $10 \mathrm{mg} / \mathrm{ml}$ in A. conyzoides leaf extract followed by $(4.50 \pm 2.747)$ on exposure to concentration $8 \mathrm{mg} / \mathrm{ml}$, but lowest in the control. The result also revealed that the larval mortality of $A$. aegypti vary in a dose dependent manner. However, the effect of $A$. conyzoides leaf extract on the larval mortality was significantly $(\mathrm{p}<0.05)$ different between concentrations and the control.

Table 1 also indicates that the mean larval mortality of $A$. aegypti $(3.25 \pm 2.598)$ was recorded higher on exposure to 10 $\mathrm{mg} / \mathrm{ml}$ of $H$. suavolens leaf extract followed by those of 8 $\mathrm{mg} / \mathrm{ml}(2.58 \pm 2.065)$ but lowest in the control. The result also revealed that the larval mortality of $A$. aegypti vary in a dose dependent manner. However, the effect of $H$. suavolens leaf extract on the larval mortality was significantly $(p<0.05)$ different between concentrations and the control.

Mean Larvicidal Mortality of $A$. aegypti exposed to $A$. conyzoides and $H$. suaveolens Leaf Extracts at Various Exposure periods (in hours)

The result shown in Table 2 indicate that the mean larval mortality of $A$. aegypti $(4.33 \pm 3.597)$ was recorded highest at 3 hours of exposure to $A$. conyzoides leaf extract followed by 6 hrs $(2.56 \pm 2.526)$ but lowest at 9 hours $(1.22 \pm 1.215)$. The result also revealed that the larval mortality of $A$. aegypti vary in a time dependent manner. However, the effect of $A$. conyzoides leaf extract on the larval mortality was significantly $(\mathrm{p}<0.05)$ different between the various time of exposure.

Table 1: Mean larvicidal mortality of A. aegypti exposed to various concentrations of $A$. conyzoides and $H$. suavolens after 24 hours

\section{Concentrations Mean Mortality of A. aegypti \pm SD} (mg/ml)

A. Conyzoides H. suaveolens

$\begin{array}{lll}\text { Control } & \text { ND } & \text { ND } \\ 10 & 4.92 \pm 3.605^{\mathrm{cb}} & 3.25 \pm 2.598^{\mathrm{d}} \\ 8 & 4.50 \pm 2.747^{\mathrm{c}} & 2.58 \pm 2.065^{\mathrm{cd}} \\ 6 & 2.58 \pm 1.621^{\mathrm{b}} & 1.75 \pm 1.357^{\mathrm{bc}} \\ 4 & 1.58 \pm 0.900^{\mathrm{ab}} & 1.42 \pm 1.165^{\mathrm{b}} \\ 2 & 1.08 \pm 0.996^{\mathrm{a}} & 0.58 \pm 0.793^{\mathrm{a}}\end{array}$




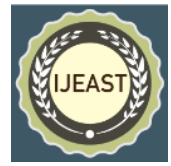

Columns with different superscripts are significantly different $(\mathrm{p}>0.05)$

ND: not detected

Table 2 revealed that the mean larval mortality of $A$. aegypti (3.11 \pm 2.698$)$ was recorded higher after 3 hours of exposure to $H$. suavolens leaf extract followed by $6 \mathrm{hrs}(1.50 \pm 1.425)$, but lowest at 24 hours $(0.83 \pm 1.098)$. The result also revealed that the larval mortality of $A$. aegypti vary in a time dependent manner. However, the effect of $H$. suavolens leaf extract on the larval mortality was significantly $(\mathrm{p}<0.05)$ different between the various time of exposure.

Table 2: Mean Larvicidal mortality of A. aegypti exposed to various concentration of $A$. conyzoides and $H$. suavolens at various time of exposure

\begin{tabular}{|c|c|c|}
\hline \multirow{2}{*}{$\begin{array}{l}\text { Time of exposure } \\
\text { (hrs) }\end{array}$} & \multicolumn{2}{|c|}{ Mean Mortality of A. aegypti \pm SD } \\
\hline & A. conyzoides & H. suaveolens \\
\hline 3 & $4.33 \pm 3.597^{\mathrm{b}}$ & $3.11 \pm 2.698^{\mathrm{b}}$ \\
\hline 6 & $2.56 \pm 2.526^{\mathrm{a}}$ & $1.50 \pm 1.425^{\mathrm{a}}$ \\
\hline 9 & $1.22 \pm 1.215^{\mathrm{a}}$ & $0.94 \pm 0.873^{\mathrm{a}}$ \\
\hline 24 & $1.67 \pm 1.645^{\mathrm{a}}$ & $0.83 \pm 1.098^{\mathrm{a}}$ \\
\hline
\end{tabular}

Columns sharing similar superscripts are no significantly different at $p>0.05$

Percentage mortality of Aedes aegypti exposed to A. conyzoides and $\boldsymbol{H}$. suavolens extracts

Figure 1 revealed that $A$. conyzoides extract caused the highest percentage mortality of Aedes aegypti larva than $H$. suavolens. However, there was no significant difference between the mean mortality of the two plant extracts $(p>0.05)$.

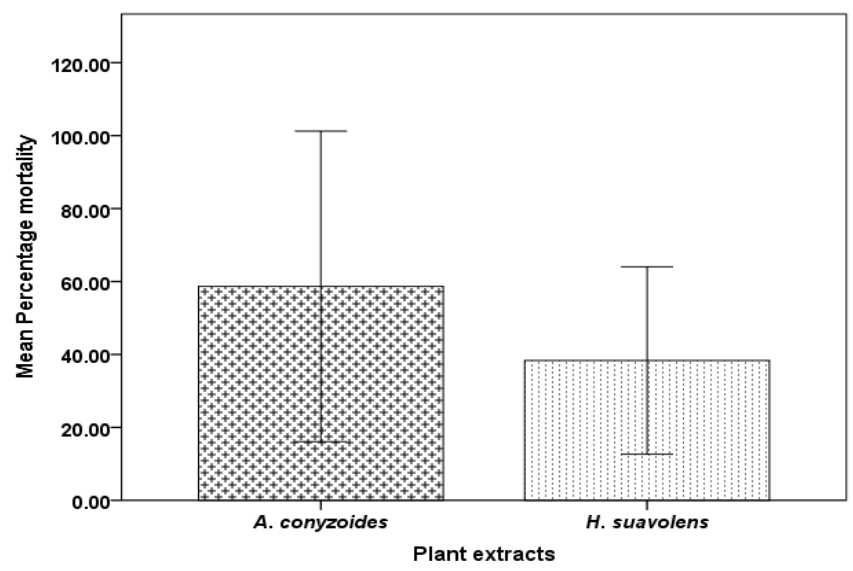

Figure 1: Percentage Mortality of Aedes mosquito larva exposed to two plant extracts

Lc 50 of $A$. conyzoides and $H$. suaveolens extracts against $A$. aegypti Larva
The median lethal concentration $\left(\mathrm{LC}_{50}\right)$ for A. conyzoides and $H$. suaveolens value based on Probit analysis were however found to be $4.30 \mathrm{mg} / \mathrm{ml}$ and $1.81 \mathrm{mg} / \mathrm{ml}$ respectively for acute 24 hours test and is as presented in figure 2 and 3 below. Figure 2 revealed a strong, linear relationship $\left(\mathrm{R}^{2}=0.980\right)$ between the mortality of $A$. aegypti exposed to A. conyzoides. Figure 3 also revealed a strong, linear relationship $\left(\mathrm{R}^{2}=0.634\right)$ between the mortality of $A$. aegypti exposed to $H$. suaveolens.

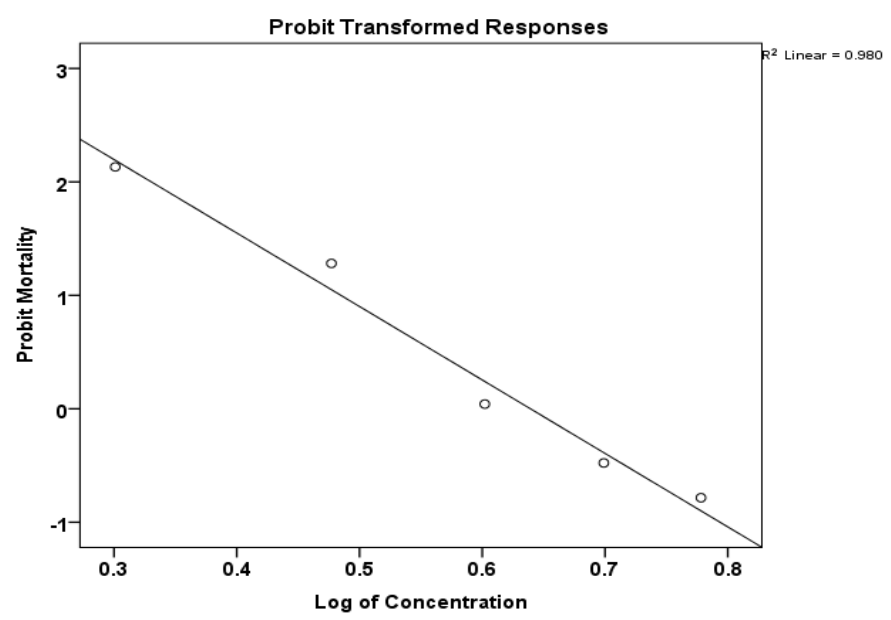

Figure 2: Probit regression line for response of A. aegypti to ethanolic extract of $A$. conyzoides

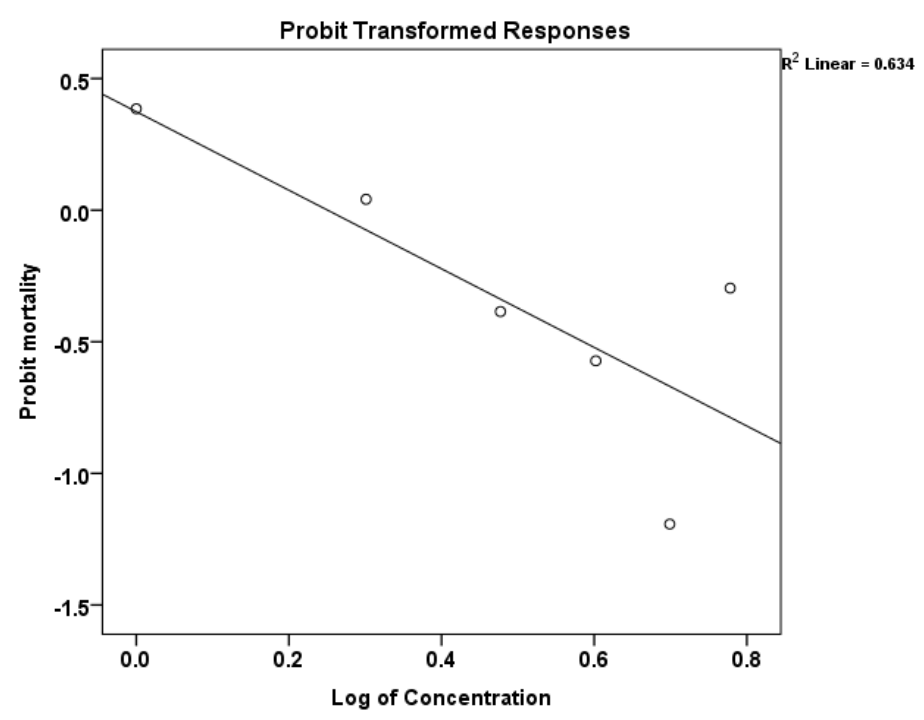

Figure 3: Probit regression line for response of A. aegypti to ethanolic extract of $H$. suaveolens

\section{DISCUSSION}

The result of this study showed that ethanol leaf extract of Ageratum conyzoides possesses larvicidal activity against Aedes aegypti, since it caused larval mortality. This is in line 


\section{International Journal of Engineering Applied Sciences and Technology, 2020 \\ Vol. 4, Issue 10, ISSN No. 2455-2143, Pages 304-309 \\ Published Online February 2020 in IJEAST (http://www.ijeast.com)}

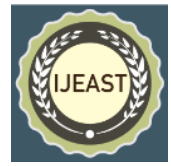

with the findings of Massuod et al. (2014). Hyptis suaveolens also possesses potency as larvicides against Aedes aegypti, since it also caused larval mortality. This is line with the result Dawet et al. (2016).

The result of Mean Larvicidal Mortality of A. aegypti exposed to various concentrations of $A$. conyzoides revealed that the larval mortality of $A$. aegypti vary in a dose dependent manner thus, there was increase in mortality as concentration were increased, with significant difference $(\mathrm{p}<0.05)$ between mortality in concentrations and control. The larva mortality was also found to increase as concentration increases and the highest performance of $A$. conyzoides was at concentrations $15 \%, 20 \%$ and $50 \%$ in comparison to concentration $5 \%$ and $10 \%$. Also, there was also increase in mortality as concentration increased, with significant difference $(\mathrm{P}<0.05)$ between mortality across concentrations and control as in $A$. conyzoides. Also, this $H$. suaveolens result is line with the preliminary findings by Dawet et al. (2016) using Ethanol leaf extract of the same plant on Anopheles Mosquito Larvae. There was also increase in mortality as concentration increased with highest mortality recorded at $500 \mathrm{mg} / \mathrm{l}$.

The result of mean larval mortality rate shows that activity of leaf extracts of $A$. conyzoides and $H$. suaveolens on $A$. aegypti reduces as time passes, with significant difference $(\mathrm{p}<0.05)$ between the various time of exposure. This shows that activity reduces as time passes. This is in agreement with the findings recently done by Dawet et al. (2016) using ethanol leaf extract of Hyptis suaveolens and Chenopodium ambrosoideson on Anopheles mosquito larvae. The mortality was recorded highest at the first 3 hour of assay on Hyptis suaveolens. In Comparism, the percentage mortality was higher in leaf extracts of Ageratum conyzoides than Hyptis suaveolens. This is in agreement with previous findings of Okigbo et al. (2010), when Azadirachta indica (Juss) and Ocimum gratissimum (L.) was compared with $H$. suaveolens. The percentage mortality of Leaf extract of Azadirachta indica (Juss), and Ocimum gratissimum (L.) were greater than that of $H$. suaveolens. However, there was no significant difference $(\mathrm{P}>0.05)$ between mortality of $A$. aegypti on exposure to $A$. conyzoides and $H$. suaveolens. This indicates that the two leaf extracts have similar effect on larval mortality of $A$. aegypti.

\section{CONCLUSION}

The study on larvicidal activity of leaf extract of Ageratum conyzoides and Hyptis suaveolens against A. aegypti showed that the ethanolic leaf extracts of both plants can be used as larvicides against Aedes aegypti. Since mosquitoes have developed resistance against currently used insecticides thereby, making effective control difficult and the adverse effects of these conventional insecticides on the environment and animals, including human could be amended by the use of safer insecticides and larvicides of plant origin that could be used in the control of the vector that transmits these diseases.

\section{REFERENCE}

[1] Adeleke, M. A., Mafiana, C. F., Idowu, A. B., SamWobo, S. O. and Idowu, O. A. (2010). Population dynamics of indoor sampled mosquitoes and their implication in disease transmission in Abeokuta, SouthWestern Nigeria. Journal of Vector Borne Disease, 47: 33-38.

[2] Ahmed, H.H., Kamal, I., O.H. and Ramky, R.M. (2004). Studies on the molluscidal and Larvicidal properties of Solanum nignum (L) leaves ethanol. Journal of the Egyptian Society of Parasitology, 31:839-843.

[3] Ansori, A.N.M., Supriyadi, A.P. and Maria, V. (2015). Effectivity of Non Polar Extract Fraction from Key Lime (Citrus aurantifolia) and Kaffir Lime (Citrus hystrix) Leaves against Aedes aegypti Larvae. Proceeding of the 5th Annual Basic Science International Conference, Malang, Indonesia, pp131.

[4] Beatty, M.E., Letson, W., Edgil, D.M. and Margolis, H. (2007). Estimating the total world population at risk for locally acquired dengue infection. Proceedings of 56 the Annual Meeting of American Society of Tropical Medicine and Hygiene, Philadelphia, Pennsylvania, USA, pp 1-8.

[5] Chaithong, U., Wej, C., Kittichai, K., Atchariya, J, Pongsri, T., Dana, C., Daruna, C., Benjawan, T., and Benjawan P. (2006). Larvicidal effect of pepper plants on Aedes aegypti (L.) (Diptera: Culicidae). Journal of Vector Ecology, 31 (1): 138-144.

[6] Dawet, A., Ikani, A. G. and Yaku, D. P. (2016). Larvicidal Effects of Hyptis suaveolens and Chenopodium ambrosoides on Anopheles Mosquito Larvae. International Journal of Scientific \& Engineering Research, 7(1):456- 470.

[7] Govindarajan, M., Yogalakshmi, K., Sivakumar, R. and Veerakumar K.(2013). Larvicidal property of Vetiver essential oil(Vetiveriazizanoides.L) A gainst Culex tritaeniorhynchus (Diptera:Culicidae). International journal of currentscience and technology, 2(1):1 -3.

[8] Jang, Y.S., Kim, M.K., Ahn, Y.S and Lee, H.S. (2002). Larvicidal activity of Brazilian plant against Aedes 


\section{International Journal of Engineering Applied Sciences and Technology, 2020 \\ Vol. 4, Issue 10, ISSN No. 2455-2143, Pages 304-309 \\ Published Online February 2020 in IJEAST (http://www.ijeast.com)}

aegypti and Culex pipiens (Diptera: Culicidae). Agricultural Chemistry and Biotechnology, 4: 131-134.

[9] Kamaraj, C., Rahuman, A.A., and Bagavan, A. (2008). Antifeedant and larvicidal effects of plant extracts against Spodoptera litura (F.), Aedes aegypti L. and Culex quinquefasciatus Say. Parasitology Research, 103(2): 325-331.

[10] Kumar, S., Mishra, M., Wahab, N., and Warikoo R.(2014). Larvicidal, repellent, and irritant potential of the seed-derived essential oil of Apium graveolens against dengue vector, Aedes aegypti L. (Diptera: Culicidae). Frontiersi Public Health: Epidemiology, 2 (147): 1-6.

[11] Madhumathy, A.P., Aivazi, A. and Vijayan, V.A. (2007). Larvicidal efficacy of Capsicum annum against Anopheles stephensi and Culex quinquefasciatus. Journal of Vector Borne Diseases, 44(3):223-226.

[12] Massuod , W. A. M. Raqib, S.M. A. Budiharjo and Mahajoena, E. (2014). Larvicidal potentiality of the bandotan (Ageratum conyzoides) leaves for controlling the three important species of mosquitoes (Aedes aegypti, Culex quinquefasciatus and anopheles maculatus). IJCBS research paper, 1: 33-43.

[13] Mgbemena, I. C. (2010). Comparative Evaluation of Larvicidal Potentials of Three Plant Extracts on Aedes aegypti. Journal of American Science, 6(10): 435-440.

[14] Nganjiwa, J.I., Pukuma, M.S., Philimon, J., and Ekundayo T.M. (2O15). Evaluation of Larvicidal Properties of Leaves and Root Ethanolic Extracts of Some Plants Herbs against Fourth Instar Mosquito Larvae. International Journal of Scientific and Research Publications, 5(2): 13.

[15] Okeke, J. J., Mogbo, T. C. And Nwakwusi, C. A. (2013). Comparative Study On The Abundance Of Mosquitoes In Temporary And Permanent Habitats In Awka, Anambra State. American Journal of Life Science Researches, 1(4): 192-199.

[16] Okigbo, R.N., Okeke, J.J. and Madu, N.C. (2010). Larvicidal effects of Azadirachta indica, Ocimum gratissimum and Hyptis suaveolens against mosquito larvae. Journal of Agricultural Technology, 6(4): 703719.

[17] Onyido, A.E., Ezeani, A.C., Irikannu, K.C., Umeaneto, P.U., Egbuche, C.M., Chikezie, F.M. and Ugha , C.N.
(2010). Anthropophilic Mosquito Species Prevalence in Nibo Community, Awka South Local Government Area, Anambra State, Southeastern Nigeria. Journal of Epidemiology \& Clinical Medicine, 2(1): $14-20$.

[18] Prajapati, V. Tripathi, A. K Aggarwal, K. K. and Khanuja, S. P. S.(2005). "Insecticidal, Repellent and Oviposition-De- terrent Activity of Selected Essential Oils against Ano- pheles stephensi, Aedes aegypti and Culex quinquefasciatus," Bioresource Technology, 96(16): 1749-1757.

[19] Salunkhe, R.B, Patil, S.V, Patil, C.D, and Salunke, B.K.(2011). Larvicidal potential of silver nanoparticles synthesized using fungus Cochliobolus lunatus against Aedes aegypti (Linnaeus, 1762) and Anopheles stephensi Liston (Diptera: Culicidae). Parasitology Research, 109: 823-831.

[20] Senthilkumar, A., Kannathasan, K., and Venkatesalu V. (2008). Chemical constituents and larvicidal property of the essential oil of Blumea mollis (D. Don) Merr. against Culex quinquefasciatus. Parasitology Resource, 103: 959962.

[21] Singh, S. B. Devi, W. R., Marina A, W. I. Devi, N. Swapana and C. B. Singh (2013). Ethnobotany, phytochemistry and pharmacology of Ageratum conyzoides Linn (Asteraceae). Journal of Medicinal Plants Research, 7(8):371-385.

[22] W.H.O. (1986). Instructions for determining the susceptibility or resistance of mosquito larvae to insecticides. World Health Organization, Mimeograph Document, WHO/ VBC / 81.807, Geneva, Switzerland.

[23] W.H.O. (1998). Report of the WHO informal consultation on the evaluation on the testing of insecticides, CTD/WHOPES/IC/96.1.Geneva, pp69

[24] W.H.O. (2014). A global brief on vector-borne diseases. (WHO/DCO/WHD/2014.1), Geneva.

[25] Webb, C.E. (2008). "Mosquito ecology: field sampling methods. Australian Journal of Entomology, 47(4):382383. 